University of Nebraska - Lincoln

DigitalCommons@University of Nebraska - Lincoln

Egyptian textiles and their production: 'word' and 'object'

$3-2-2020$

\title{
What flaws can tell: a case study on weaving faults in Late Roman and Early Medieval weft-faced compound fabrics from Egypt
}

\author{
Barbara Köstner \\ Universität zu Köln
}

Follow this and additional works at: https://digitalcommons.unl.edu/egyptextiles

Part of the Africana Studies Commons, African Languages and Societies Commons, Classical Archaeology and Art History Commons, Fiber, Textile, and Weaving Arts Commons, History of Art, Architecture, and Archaeology Commons, and the History of Science, Technology, and Medicine Commons

Köstner, Barbara, "What flaws can tell: a case study on weaving faults in Late Roman and Early Medieval weft-faced compound fabrics from Egypt" (2020). Egyptian textiles and their production: 'word' and 'object'. 7.

https://digitalcommons.unl.edu/egyptextiles/7

This Article is brought to you for free and open access by the Centre for Textile Research at DigitalCommons@University of Nebraska - Lincoln. It has been accepted for inclusion in Egyptian textiles and their production: 'word' and 'object' by an authorized administrator of DigitalCommons@University of Nebraska - Lincoln. 


\title{
What flaws can tell: a case study on weaving faults in Late Roman and Early Medieval weft-faced compound fabrics from Egypt ${ }^{1}$
}

\author{
Barbara Köstner
}

Silk samites from Late Roman and Early Medieval Egypt are well-known objects in museum collections all over the world. One group of fragments, the so-called Akhmim silks, show a mechanically repeated floral pattern. More than 100 examples with this design are known; the fragments bear striking similarities in design and technique. Were they woven in the same workshop? If all or at least a large number of pieces could be traced back to several batches of production, this would lead to further insights concerning the economics of early silk weaving. A detailed analysis of two exemplary pieces reveals features that are not seen at first sight: small mounting errors or faults during weaving can be followed warp- and weft-wise. Together with the technical details these "flaws" are a fingerprint of the textile that is unique and visible in all fragments woven within the same warp on the loom. In addition, the weaving faults provide details about the weaving process and the advanced looms that were used. This paper offers an approach towards the identification and characterisation of woven-in irregularities and a perspective on the possibilities they offer to research on complex fabrics. ${ }^{2}$

\section{Silks from Egypt}

Among the many different fabrics that were discovered in the Roman to Early Medieval necropoleis of Egypt around the turn of the $2 \mathrm{O}^{\text {th }}$ century was a remarkable amount of silk textiles. In 1891 the Swiss collector and art historian Robert Forrer published his catalogue Römische und Byzantinische Seiden-Texilien aus dem Gräberfelde von AchmimPanopolis, dedicated solely to the luxurious and mostly patterned silk textiles found in Akhmim. ${ }^{3}$ Further silks from Akhmim and other find-spots in Egypt were published in early excavation reports, ${ }^{4}$ catalogues of collections, ${ }^{5}$ general overviews on so-called Coptic textiles or the history of silk textiles in particular. ${ }^{6}$

Published in Maria Mossakowska-Gaubert, ed., Egyptian Textiles and Their Production: 'Word' and 'Object' (Hellenistic, Roman and Byzantine Periods) (Lincoln, NE: Zea Books, 2020). doi 10.32873/unl.dc.zea.1084

1. Research on the technique of silk samites is part of my ongoing PhD project Komplexe Seidengewebe im Gebiet des römischen Reiches aus der Spätantike und dem Frühmittelalter (3. bis 8. Jh. n. Chr.) under the supervision of Professor Sabine Schrenk, Christliche Archäologie, Universität Bonn.

2. My sincere thanks go to the colleagues who made it possible for me to analyse some Akhmim silks in person and to take the time I needed to trace irregularities: Judith Goris and Chris-Verhecken-Lammens, formerly Phoebus Foundation / Katoen Natie, Antwerp; Anne Haslund Hansen, National Museum of Denmark, Kopenhagen; Annette Paetz gen. Schieck, Deutsches Textilmuseum, Krefeld; Imogen Liang and Amandine Merat, both British Museum, London; Mariam Rosser-Owen and Ana Cabrera-Lafuente, Victoria \& Albert Museum, London; and Anu Liivandi, Royal Ontario Museum, Toronto.

This research benefits a lot from the kind support from and the brilliant technical discussions with Ana Cabrera-Lafuente, Annette Paetz gen. Schieck and Chris Verhecken-Lammens.

3. Forrer 1891.

4. E.g. Forrer 1895; Gayet 1897; Gayet 1898.

5. E.g. Hampe 1896; Kendrick 1922, Wulff \& Volbach 1926.

6. E.g. Schulze 1920; von Falke 1913. 
Figure 1. Samite.

$\mathrm{B}=$ binding warp;

$\mathrm{M}=$ main warp;

1 = ground weft;

2 = pattern weft.

(Drawing (C) Barbara Köstner)

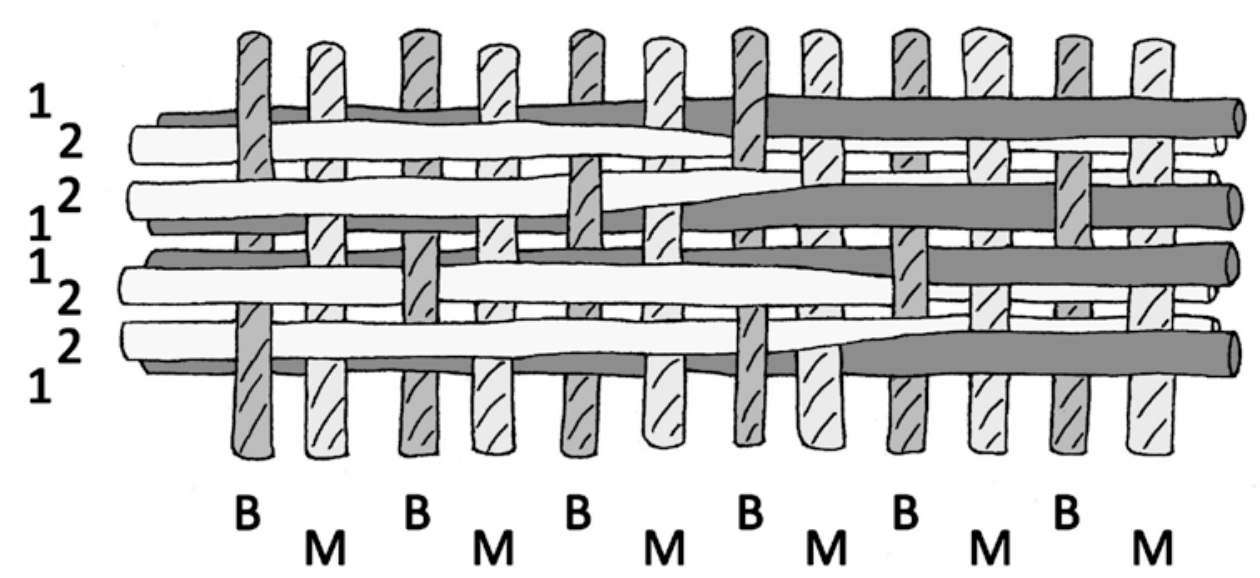

Today the pieces are distributed around museums all over the world, particularly in the major art and textile museums and private collections. A broad, multi-disciplinary approach towards these textiles is necessary to answer the emerging questions on origin, production, distribution and use of these special fabrics. ${ }^{7}$

\section{The technique of samite}

One major group of silk textiles from Late Roman and Early Mediaeval times is woven in weft-faced compound twill, called samite. In this technique, two warps and two or more wefts are used to produce a fabric that shows the pattern in contrasting colours (see fig. 1). On the reverse the pattern appears in inversed colours.

Two warps are employed for the fabric: one for the $1 / 2$ twill binding of the fabric (binding warp / Bindekette / chaîne de liage, marked " $B$ " in fig. 1) and one for the separation of the pattern sheds (main warp / Hauptkette / chaîne pièce, ${ }^{8}$ marked " $M$ " in fig. 1 ). The warp threads with different functions lie next to each other, always one after another following the configuration B, M, B, M. This is described by the "warp proportion", which is $1: 1 .{ }^{9}$ Only the binding warp is visible on the surface of the fabric; the main warp remains unseen and is completely covered by the wefts. Two wefts of contrasting colours are used in one binding shed, and the main warp separates them to push one to the front and one to the rear side of the fabric to form the pattern.

\section{Group of so-called Akhmim silks}

The total number of silk samite fragments from the $3^{\text {rd }}$ to $8^{\text {th }}$ century $\mathrm{AD}$ in museums and private collections reaches several hundred. Groups are formed by provenience and iconography as well as by technical features. The group of the so-called Akhmim silks is named by the find-spot of Akhmim in Upper Egypt, where a number of silks with the same design have been discovered. ${ }^{10}$ Primarily, they are dual-coloured samites with the pattern in a light cream colour on a darker background; a central motif is framed by a border of repeating elements. Following the approach of Antoine De Moor, Sabine Schrenk and Chris VerheckenLammens (2006), the focus of this article is set on the narrow definition of the constituent figures of this group: a central plant motif with distinct features and framing borders of alternating mirrored palmettes on all elements ${ }^{11}$ (see fig. 2). Forrer has already noted that this floral pattern

7. A detailed overview on the history of the research on so-called Coptic textiles and a perspective for the future is provided by Thomas 2007.

8. For the vocabulary, see CIETA 1964. The term "main warp" may be misleading at first sight, as it naturally indicates the principal warp in the fabric. In samite the invisible main warp is crucial for the forming of the pattern, but has no binding function. It may be tempting to call this pattern-forming warp "pattern warp", but this term is already used for supplementary warps that are visible on the surface (synonym for pattern warp: flushing warp / Flottierkette / chaîne poil, see Burnham 1980, p. 98 and 180). Occasionally "inner warp" is used as a synonym for the main warp (Burnham 1980, p. 180).

9. As an example: some later silk samites have a different warp proportion of 1:2 meaning that 1 binding warp is followed by two main warps.

10. De Moor et al. 2006, p. 85 .

11. For a detailed description of the pattern, see De Moor et al. 2006, p. 85-88; the only difference the author would like to suggest is to reinterpret what De Moor et al. called "large leaves" (p. 85) as "buds". 


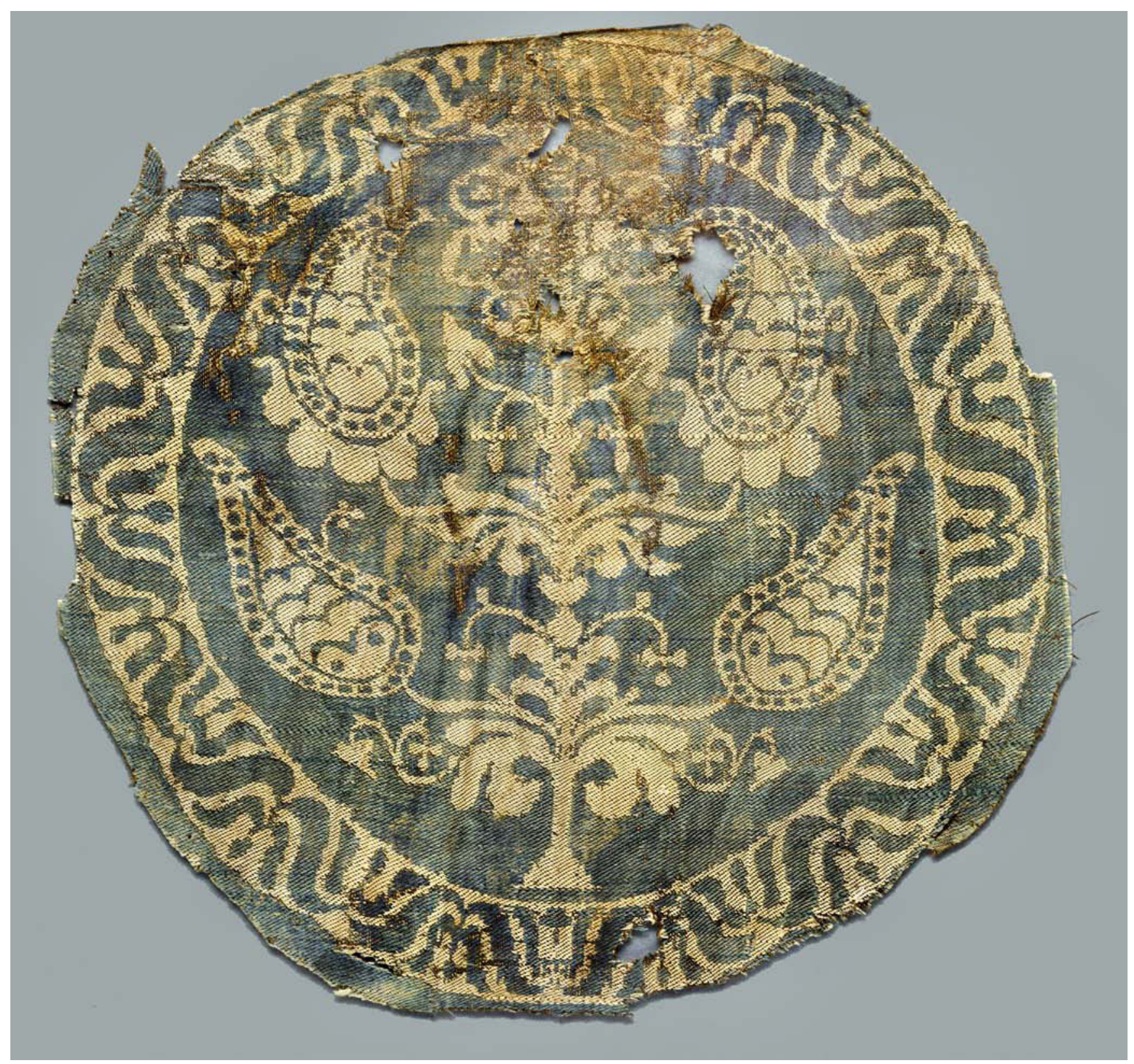

Figure 2. Roundel, silk, 22.3 x 22.5 cm: Victoria \& Albert Museum, Inv. No. 355-1887. (Photo (C) Victoria \& Albert Museum).

occurs very often and might have been very popular in Akhmim. ${ }^{12}$ Currently more than 100 samites with this special iconography are known from different collections. ${ }^{13}$

An advanced division of the Akhmim silks with plant motif can be made regarding the stylistic differences formed by a larger warp step. In pieces with very fluent pattern and organic appearance every thread of one pattern unit of the main warp was operated singly (warp step =1). These pieces can easily be distinguished from those with a highly stylised appearance, which is formed by small pixel-like

\section{Forrer 1891, p. 16.}

13. De Moor et al. 2006, p. 88-89 list 20 pieces with verified find-spot and a further 43 pieces of this group with no verified findspot. To these 63 examples can be added 40 pieces from the author's recent research; it is most likely that more pieces will be added to the list. A broader view of this group of silks is held by Forrer 1891 p. 14-16; von Falke 1913, p. 43-47; MartinianiReber 1986, p. 80-81 and Muthesius 1997, p. 81, who include similar dual coloured samites with figural depictions in roundels and clavi and heart-shaped framing ornaments. 


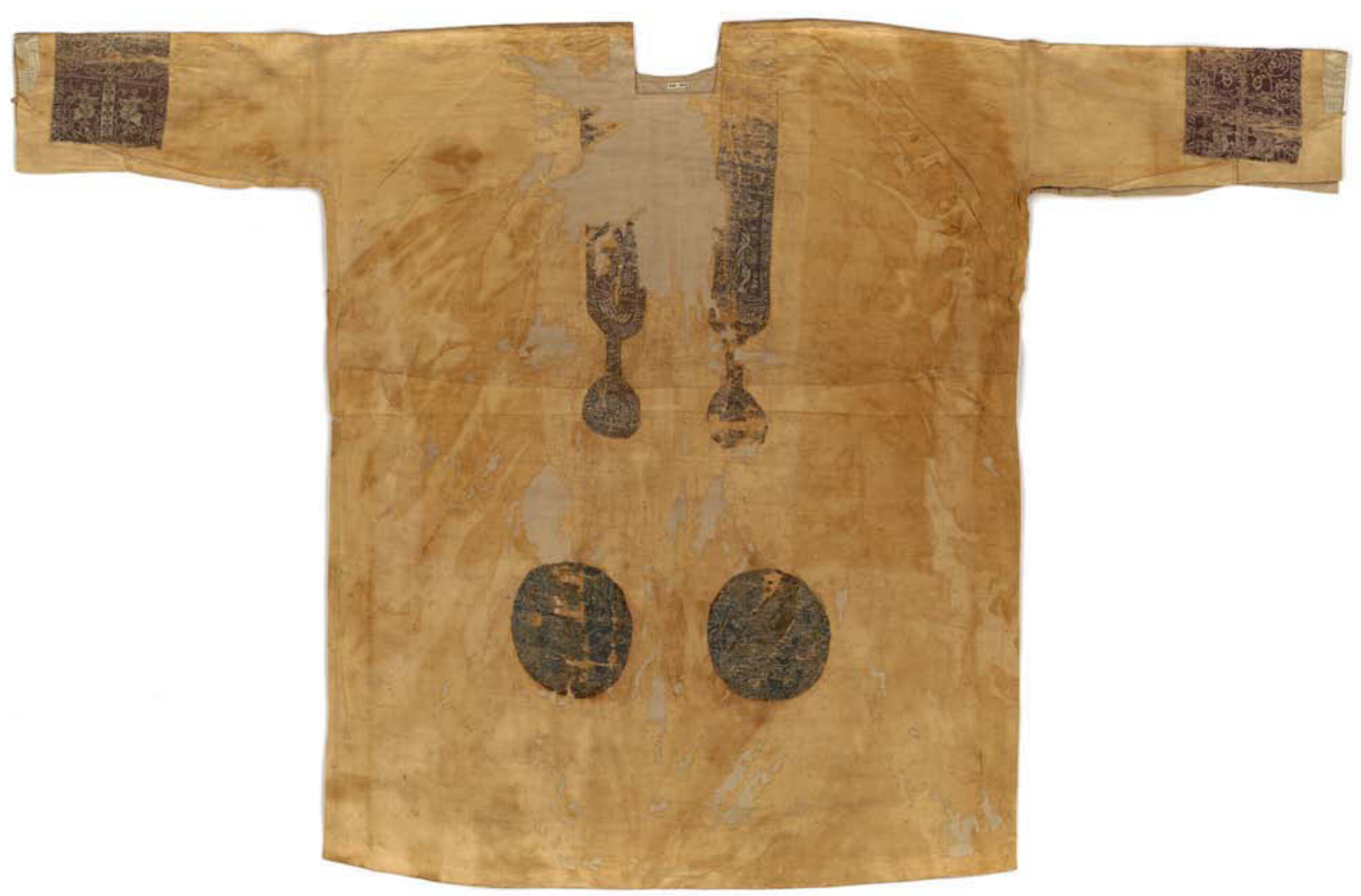

Figure 3. Linen tunic with sewn-on silk panels, height $137.2 \mathrm{~cm}$, width: $210.5 \mathrm{~cm}$ incl. sleeves, width of hem: $110 \mathrm{~cm}$ : Victoria \& Albert Museum, Inv. No. 820-1903. (Photo (C) Victoria \& Albert Museum).

blocks, where the threads of the main warp were operated in groups (warp step $=3$ or more) ${ }^{14}$ Further technical details differ between the organic and the stylised group, such as the direction of twill, weft proportion and weft sequence, as well as weft density. ${ }^{15}$

\section{Use}

The Akhmim silks with plant motif are found in different shapes: roundels that have been cut close to the edge of the medallion; ${ }^{16}$ panels that have been cut from the fabric in a rectangular shape showing the remains of rosette ornaments in the angles between the medallions; ${ }^{17}$ clavi with round pendants at the ends; ${ }^{18}$ and large rectangular decorations with a central floral circle ornament and mirrored horsemen. ${ }^{19}$ Traces of sewing and seam allowances indicate that the different elements were used mainly as decorations for tunics. ${ }^{20}$ One complete garment now in the Victoria \& Albert Museum, London (fig. 3), shows a set of two clavi, four orbiculi and two manicae sewn onto a plain

14. De Moor et al. 2006, p. 92. The grouping of main warp threads in blocks (= larger warp step) leads to a loom-setup where the weaver has to handle only c. 40-6o pattern blocks instead of more than 200 single main warp threads per pattern unit.

15. See analysis by Chris Verhecken-Lammens in De Moor et al. 2006, Table 2, p. 93. The author's research on further pieces backs these findings.

16. E.g. Nürnberg, Germanisches Nationalmuseum, Inv. No. Gew350 (Hampe 1896, no. 350); Victoria \& Albert Museum, Inv. No. 355-1887; 2066-1900 (Kendrick 1922, no. 798).

17. E.g. Wien, MAK, Inv. No. T 10051-01-1953 (Noever 2005, no. 114); Phoebus Foundation, Inv. No. 657 (De Moor et al. 2008 , p. 194-195).

18. E.g. Deutsches Textilmuseum, Inv. No. o0120A (Paetz gen. Schieck 2003, no. 217).

19. E.g. Victoria \& Albert Museum, Inv. No. 303-1887 (Kendrick 1922, no. 800).

20. Only a few pieces exist that do not fit the standard scheme of rectangular or circuit panels and show several roundels in one larger piece of fabric, e.g. Washington, Dumbarton Oaks, Byzantine Collection, Inv. No. BZ 1977.2 (Thomas 2017, p. 65, fig. 5.22) which shows four complete and four half roundels in one large sheet. 
white linen tunic. ${ }^{21}$ This singular tunic is a surviving example of the Akhmim silks in their original context and shows the use of the panels. It is remarkable that the sleeve panels were woven with a mirrored design for the horsemen to be in the correct viewing position on both sides of the sleeves when the tunic was worn.

\section{Colour and dating}

While the most common background colour of Akhmim silks with plant motifs is a purple hue, blue, green, red and orange tones were used as well. The pattern wefts are in cream or light yellow. Ten examples have been tested for the dyestuffs used in the weft, and all examined examples showed traces of redwood as dyestuff, albeit the organic group of samites showed a broader range of colours mixed for the purple tones, including madder, indigoid, lac and tannin besides redwood. ${ }^{22}$ The warp threads can be of brown or yellow colour, consistent within one piece.

The common stylistic dating assigned these pieces to the $6^{\text {th }}-10^{\text {th }}$ century AD. ${ }^{23}$ This was narrowed by the ${ }^{14} \mathrm{C}$-dating of ten pieces which resulted in a dating from AD 650-948 (95\% probability) with an interquartile dating range for all ten fabrics of AD 687-828, with the organic type pieces dating slightly earlier than the stylised ones. ${ }^{24}$

\section{Economic relevance}

Looking at the similar patterns of the Akhmim silks with plant motif and the large number of surviving pieces, a most pertinent question is whether they were produced by the same or related workshops and where these could have been located. It is certain that the Akhmim silk panels were not woven as individual items but were cut from a length of fabric with a repeating pattern. ${ }^{25}$ The fabric produced on one loom with one warp can be regarded as one single batch of production. But the technical details alone may not suffice to prove the origin from one single batch since the overall technical features of two batches may be close to identical. To prove the affiliation of pieces to the same batch, a detailed analysis must detect irregularities in the pieces. Every silk fragment contains features that are not seen on first sight, such as mounting errors or faults during weaving that can be followed through the whole piece. These "flaws" are visible in all fragments woven within the same warp and are a "fingerprint", an individual marker of one batch. ${ }^{26} \mathrm{Re}-$ constructing the possible batches of Akhmim silks with plant motives would help to estimate the output of the silk weaving workshops and lead to further conclusions concerning the economics of early silk weaving.

\section{Technical details of Akhmim silks in organic style}

The proportion of warps in the Akhmim silks in organic type is $1: 1$, with alternating binding and main warp threads (see fig. 1). ${ }^{27}$ For both warps, single threads of silk with a twist in Z-direction were used. The twill binding is a $1 / 2$ twill in straight Z-direction. The width of the main warp is divided into several pattern units, which are each about $11 \mathrm{~cm}$ wide and have a reverse repeat (double point) with a warp step of 1 . One roundel consists of two pattern units with the mirror axis in the centre. It is still not certain how many pattern units were employed in one loom-width, but it may be eight pattern units, arranged in point repeat - or even more. ${ }^{28}$ The warp density is measured in units (here: 1 binding warp thread +1 main warp thread $=1$ warp unit) and ranges from 16-22 units/cm.

Two wefts of contrasting colours (ground weft $=1$ and pattern weft $=2$ in fig. 1) are used for each binding shed, separated by the main warp. This combination of two

21. Victoria \& Albert Museum, Inv. No. 820-1903, purchased in 1903 from L. Paul Philip, located in Cairo. Archive of the Victoria \& Albert Museum, Museum Register No. 193, Science \& Art Department, MA/30/227, p. 270 and Nominal File MA/1/P/109.

22. De Moor et al. 2006, table 3, p. 94.

23. Muthesius 1997, p. 81.

24. De Moor et al. 2006, p. 91. A silk samite with a more general Akhmim-like style from Avdat, Israel, backs this dating with a secured archaeological context dated to ante quem 636, see Baginski \& Tidhar 1978.

25. Selvedges appear only on rare occasions and so far only on one side of a panel, e.g. Phoebus Foundation, Inv. No. o842. Some panels show parts of the pattern of the next roundel in the seam allowance, e.g. Deutsches Textilmuseum, Inv. No. oo124, see Paetz gen. Schieck 2003, no. 216, p. 104.

26. Ana Cabrera suggested that warp errors due to miscounting would possibly continue in a knotted-on warp. Whether the knotting-on of a new warp to an old one was possible and practised in Late Roman to Early Medieval samite weaving is yet to be researched.

27. They are also known as single main warp twills; see Muthesius 1997, p. 81.

28. The piece at Dumbarton Oaks Byzantine Collection, Inv. No. BZ 1977.2, shows four roundels in the width of the warp. 
threads is one pass (fig. 1 shows four passes). The weft step is two passes for the organic designs, with a special way to insert the thread; the selection of the pattern shed is used for two consecutive binding sheds in the rhythm of $1,2 / 2,1$ (see fig. 1). This technique employs two shuttles for each colour. ${ }^{29}$ The weft threads of the Akhmim silks show no twist; weft density varies from 20-44 passes $/ \mathrm{cm}$.

\section{Tracing pieces from the same warp}

When tracing pieces that might have been woven in the same warp, they should first meet the following criteria:

\section{Same technical features:}

- Warp proportion

- Warp step (distinction between organic and stylised examples; within the stylised examples further differentiation is possible)

- Twill direction (the twill direction might be changed during weaving, but this seems unlikely so far)

- Twist and colour of warp threads

- Thread count

- Colour of weft (this applies weft-wise; of course it would be possible for the weaver to change colour of wefts in the length of one warp).

Due to several factors, like the application of the panels on a fabric, the time spent in the soil and conservation treatment, the warp and weft density may change slightly as could the colours. These parameters should, however, lie within a considerably narrow range.

\section{Same design:}

- Special attention should be given to small details that may differ.

All silks in this focus show a design with plant motifs and framing border with mirrored palmettes. ${ }^{30}$
If the above criteria are all met, it is a strong indicator, albeit not a proof, of pieces belonging to the same batch. To provide complete certainty that two (or more) textile fragments derive from the same warp, it is necessary to see if there are irregularities in the fabric and if these irregularities match one another.

\section{Irregularities}

With such a complex technique and fine weaving as silk samite, it is almost inevitable that irregularities appear. Every stage of the weaving process is prone to small mistakes that will not have a dramatic effect on the fabric as a whole and will only be discovered with a very close look. ${ }^{31}$

These irregularities can be detected by a simple non-invasive visual analysis. Intact and damaged fragments can be examined: thread-counter and (digital) microscope are useful instruments. ${ }^{32}$ As part of the common analysis of a fabric (cutting marks, seam allowances, sewing traces etc.) and its technical features, warp and weft are systematically searched for irregularities.

When detecting such irregularities, it is necessary to trace them in the full length of the thread (warp- or weftwise). Some irregularities occur during weaving, like broken and therefore missing warp threads, and these will not show in the full length of the warp. Other irregularities, like a change in the twill direction, are mistakes during the mounting of the warp and will be visible through the full length.

Irregularities that occur weft-wise always appear exactly in the same position in the pattern (= same shed). If the wrong main warp threads are picked in a pattern shed or the weaver forgets to insert one of the wefts, this will repeat weft-wise in all fragments woven next to each other in the same warp.

During analysis, the position of all irregularities is noted precisely. The position of warp irregularities should not only be noted in centimetres but also in the number of warp steps in relation to the next pattern marker.

Different kinds of irregularities may occur:33

29. For a detailed description, see Chris Verhecken-Lammens in De Moor et al. 2006, p. 92-93.

30. There are indications that clavi, orbiculi and manicae of one design could have been woven within the same warp; see forthcoming articles by the author.

31. In textile production the examination of the fabric and detection of irregularities is a standard procedure of quality control. While the literature focuses mainly on modern textile production, it is useful for textile archaeologists as well; see for example Herzog \& Koch 1958.

32. Beside this common set-up for analysis, Julia Galliker developed a promising application of computer vision for the analysis of weft-faced compound fabrics, which works with high resolution digital images from intact areas of textiles. It requires a set of digital instruments to capture images of a very high standard, which are then processed with a specialised software; see Galliker 2013.

33. As the research is ongoing, further points may be added to the list. 


\section{Irregularities of the basic material:}

- Diameter of warp and weft threads

- Strength of twist of the thread

- Colour of the threads

\section{Irregularities that occur before the actual weaving (warping, mounting):}

- Miscounting during the warping or mounting (e.g. double or missing warp threads-not to be confused with broken warp threads-or wrong number of threads in blocks of stylised patterns).

- Misthreading: One or several warp ends are not threaded in the correct order, the wrong shed/heddle is chosen (e.g. change in twill direction when binding warp is affected).

\section{Irregularities that occur during the weaving:}

- Broken warp threads: one binding or main warp thread is missing; the two warp ends of the other system are lying next to each other. This irregularity can be mistaken as a miscounting in mounting. In some cases the replacement of a broken warp thread can be detected.

- Floating warp threads.

- Wrong selection of pattern shed: errors in the pattern that repeat in the next pattern unit.

- Wrong selection of binding shed.

- Double wefts:

- True double (e.g. the same pass woven twice in the same binding shed).

- Double thread in same shed at end of bobbin (overlapping ends).

- Missing wefts: only one weft has been inserted; the second pattern shed of the pass is empty.

Mapping these "flaws" leads to an individual pattern of irregularities, which clearly indicates related pieces woven within the same warp.

\section{Testing the method}

During research on pieces from different museum collections, two fragments were found that appear nearly identical:34 a) Panel from the Victoria \& Albert Museum, Inv. No. 303-1887, $33 \times 23.4 \mathrm{~cm}$, fig. 4 .

b) Panel from the British Museum, Inv. No. 1904,0706.41, $30.1 \times 22.9 \mathrm{~cm}$, fig. 5 .

Both fragments bear the design of the plant-motif Akhmim silks. They are worked in the organic style and show the same pattern: in the lower half, two horsemen face each other divided by a line of pomegranates. Above the riders, the inscription ZAXAPIOY (Zachariou) is woven in Greek letters in the correct reading direction on the one side and mirrored on the other side. ${ }^{35}$ The upper halves of the pieces show a lavish pattern of tendrils and buds with a central flower. The right and the left borders are framed with the typical mirrored palmette patterns. There are no selvedges; all sides (except for the fringed end of the Victoria \& Albert piece) have been cut.

In comparison with the silk decorations on the tunic, Inv. No. 820-1903, at the Victoria \& Albert Museum, the pieces can be identified as halves of sleeve panels. Did they once belong together? The cutting lines in the middle of the central floral ornament seem to correspond, as do the technical features:

\begin{tabular}{lcc} 
& $\begin{array}{c}\text { British Museum, } \\
\text { Inv. No. } \\
\text { 1904,0706.41 }\end{array}$ & $\begin{array}{c}\text { Victoria \& Albert } \\
\text { Museum, } \\
\text { Inv. No. 303-1887 }\end{array}$ \\
\hline Warp & & \\
1/2 Twill, direction & $\mathrm{Z}$ & $\mathrm{Z}$ \\
Twist BW, MW & $\mathrm{Z}, \mathrm{Z}$ & $\mathrm{Z}, \mathrm{Z}$ \\
Colour BW, MW & brown & brown \\
Proportion & $1: 1$ & $1: 1$ \\
Units/cm & $18-20$ & $18-20$ \\
Warp step & 1 & 1 \\
Warp steps* & $215-220$ & $215-220$ \\
& & \\
Weft & none & none \\
Twist & 1:purple to blue & $1:$ purple to pink \\
Colour & (ground) & (ground) \\
& $2:$ cream (pattern) & $2:$ cream (pattern) \\
& $2 / 2$ & $2 / 2$ \\
Proportion & $1,2 / 2,1$ & $1,2 / 2,1$ \\
Sequence & 2 & 2 \\
Weft step & $33-44$ & $35-40$ \\
Pass/cm & & \\
\hline
\end{tabular}

* The total number of warp steps is difficult to count, as due to the cutting to the left and right no full pattern unit is preserved. However, separate pattern elements, like borders or figural fields, have been counted and proven to be identical.

34. I am much obliged to the staff of the British Museum and the Victoria \& Albert Museum who made it possible for me to see both pieces simultaneously in December 2018. This was only possible due to the lucky circumstance that both pieces were located at Blythe House in Kensington, London. Thanks for making the unusual meeting possible are due to: Claire AllenJohnstone, Benjamin Hinson, Suzanne Smith and Mariam Rosser-Owen, all Victoria \& Albert Museum and The Clothworkers' Centre, as well as Imogen Laing and Amandine Merat, both British Museum.

35. For the interpretation, see De Moor et al. 2006, p. 88 with further references. 


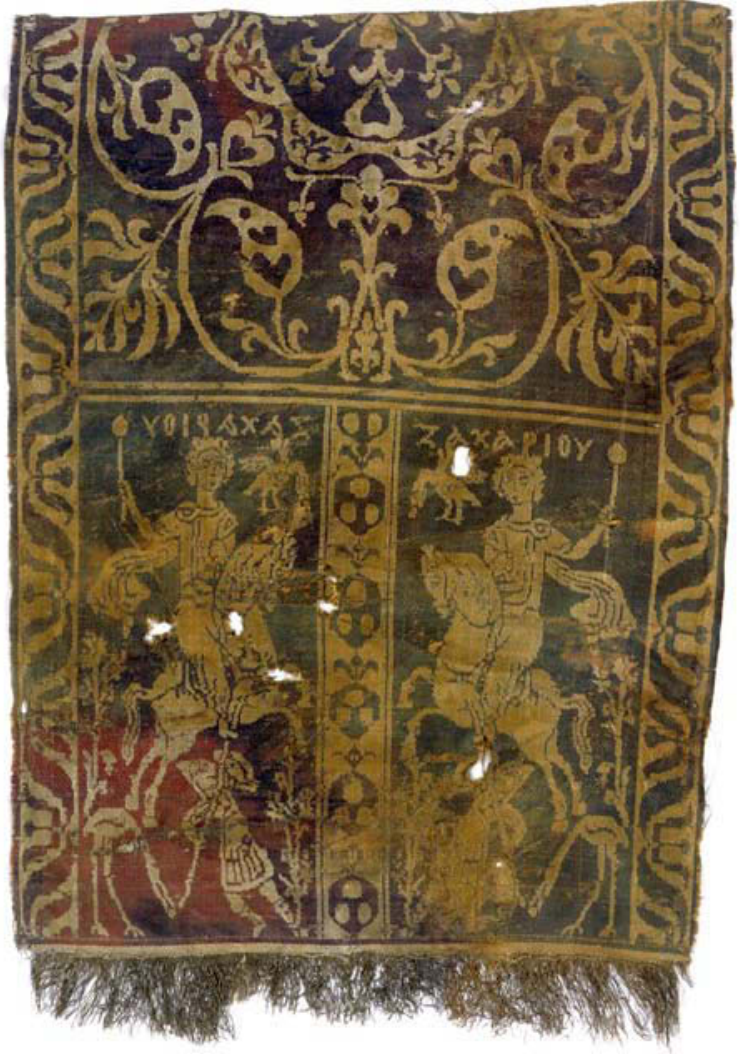

Figure 4. Panel, silk, 33 x $23.4 \mathrm{~cm}$ : Victoria \& Albert Museum, Inv. No. 303-1887. (Photo (C) Victoria \& Albert Museum).

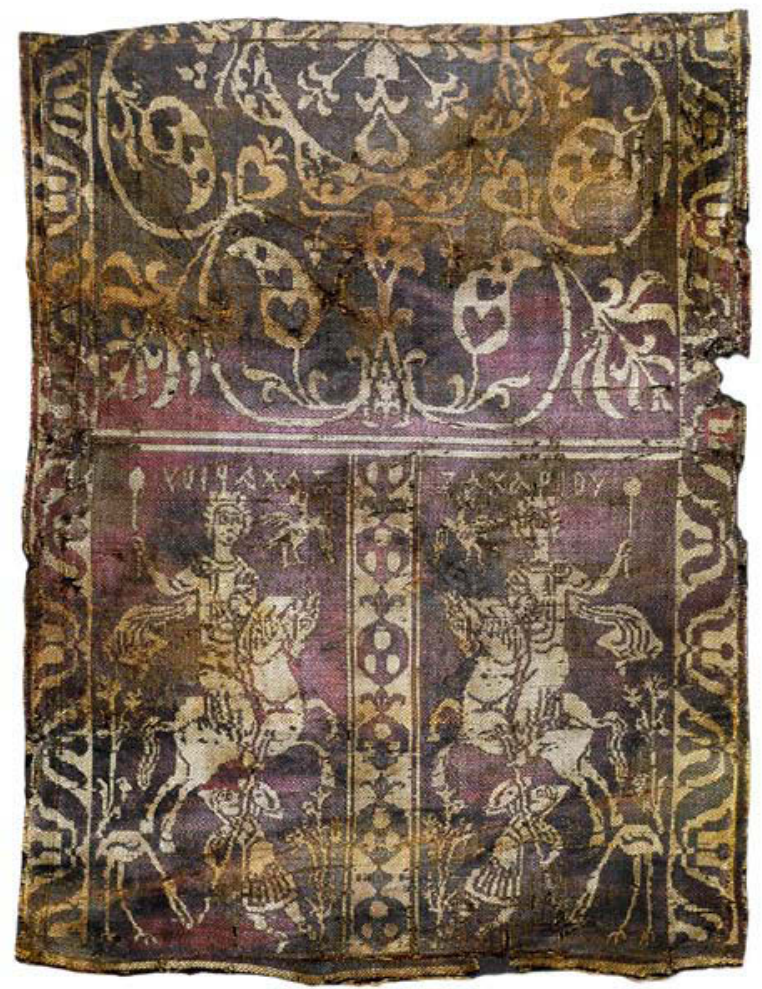

Figure 5. Panel, silk, 30.1 x $22.9 \mathrm{~cm}$ : British Museum, Inv. No. 1904.0706, 41. (Photo (C) Trustees of the British Museum).
For the reconstruction of the full panel, the pieces are joined at the cutting line, turning the British Museum piece through $180^{\circ}$ and placing it on top of the Victoria \& Albert piece. The measurements in the following paragraph relate to this new set-up (see fig. 6).

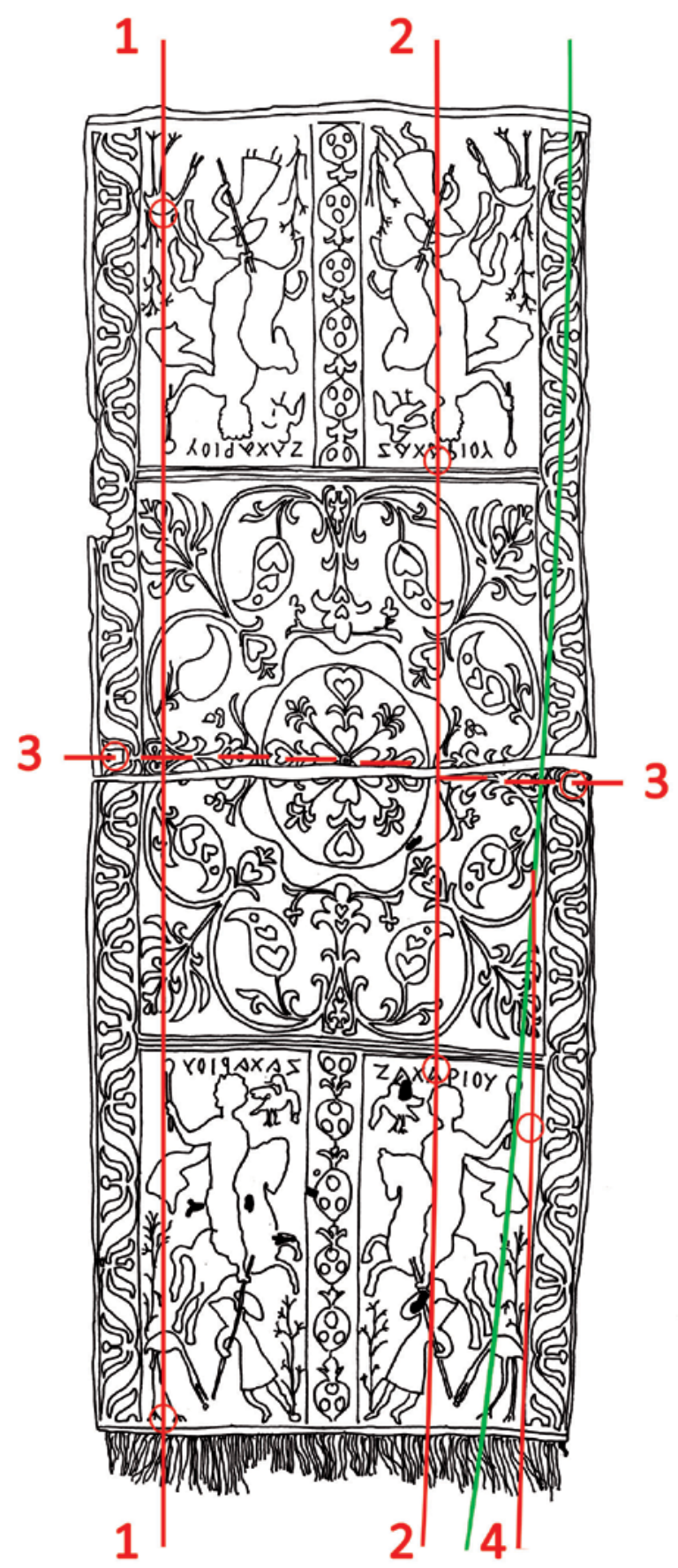

Figure 6. Sketch of the position of corresponding irregularities (red lines, 1-4) and line of wear (green) in the two pieces: British Museum, Inv. No. 1904.0706,41 (upper half) and Victoria \& Albert Museum, Inv. No. 303-1887 (lower half); red circles indicate the position of the details. (Drawing (C) Barbara Köstner). 


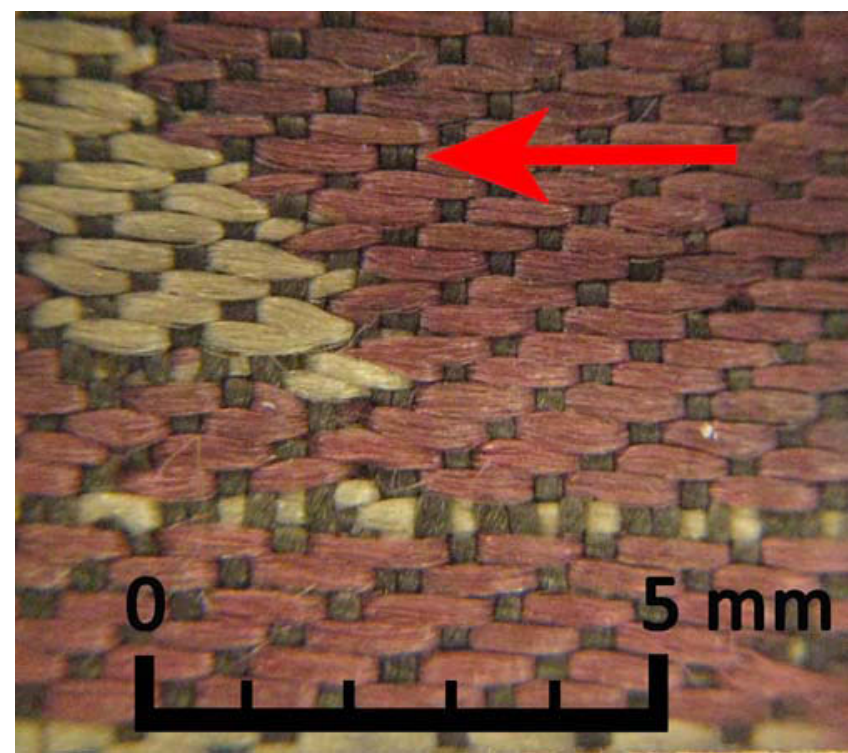

Figure 7a. Double binding warp thread in Victoria \& Albert Museum, Inv. No. 303-1887. (Photo: Barbara Köstner (c) taken courtesy of the Victoria \& Albert Museum).

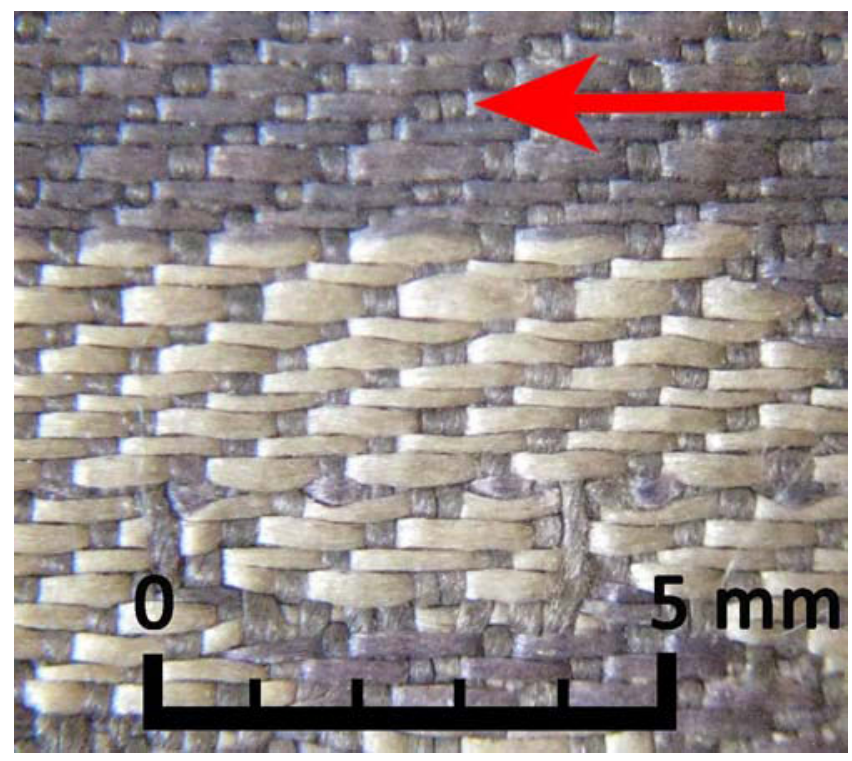

Figure $7 \mathbf{b}$. Double binding warp thread in British Museum, Inv. No. 1904.0706, 41. (Photo: Barbara Köstner (C) taken courtesy of the Trustees of the British Museum).

A closer look at the weaving irregularities gives the final proof of their relation. As the cutting line runs through the warp, it is necessary to look at all irregularities in the warp first:

1. Double binding warp thread (fig. $7 \mathrm{a}+\mathrm{b}$ ): $1 \mathrm{~cm}$ right of the left framing border and into the area with figures, thread No. 20 is double. This double binding warp is the result of an irregularity during the

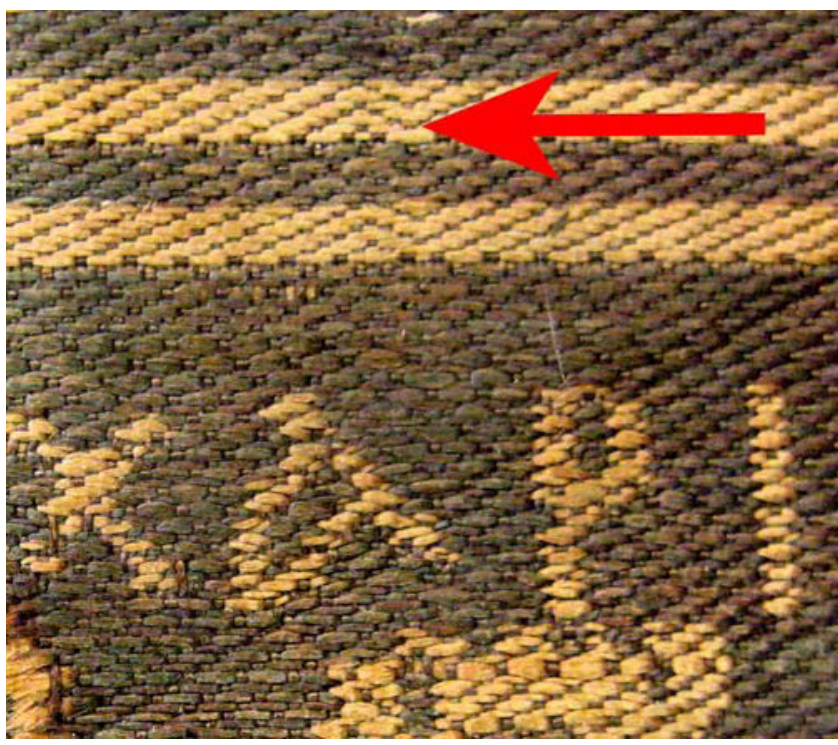

Figure 8a. Change in twill direction in Victoria \& Albert Museum, Inv. No. 303-1887. (Photo: Barbara Köstner (c) taken courtesy of the Victoria \& Albert Museum).

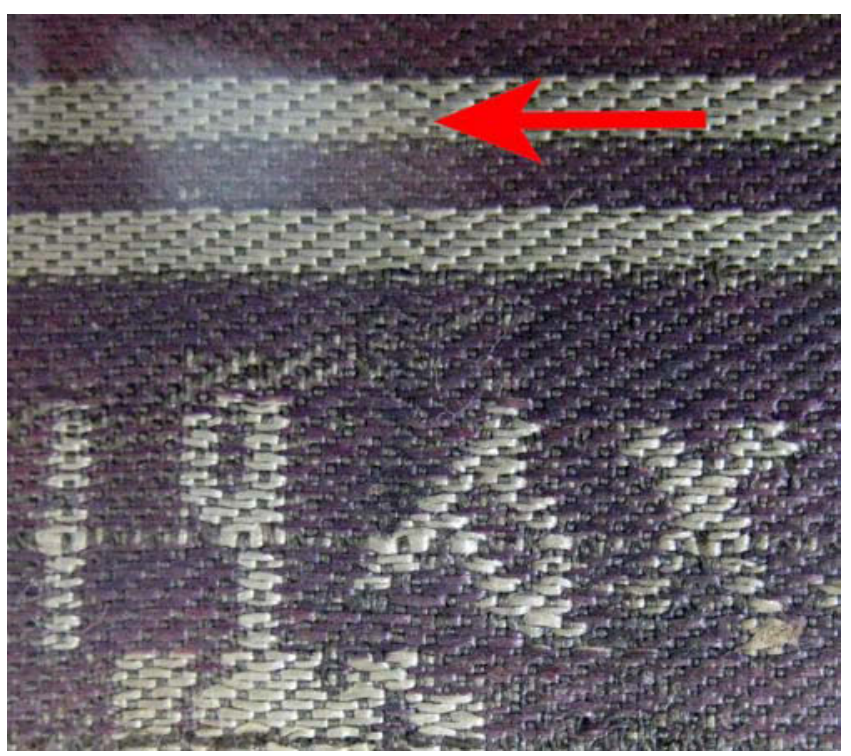

Figure 8b. Change in twill direction in British Museum, Inv. No. 1904.0706, 41. (Photo: Barbara Köstner (c) taken courtesy of the Trustees of the British Museum).

mounting of the loom (miscounting). It is impossible that this double binding warp thread is the result of a broken main warp thread, as both binding warp threads are operating in the same binding shed.

2. Change in twill direction (fig. $8 \mathrm{a}+\mathrm{b}$ ): In the left figured field, $4.8 \mathrm{~cm}$ before the right framing border starts (right side of second " $\mathrm{A}$ " of the inscription, binding warp threads No. 90+91 to the right from the middle 
pattern axis), a change in twill direction can be seen. This irregularity is a result of misthreading during mounting. The warp ends have been threaded in the wrong heddle. The normal count of a straight $1 / 2$ twill repeat is $1,2,3,1,2,3,1,2,3, \ldots$ while in this small area the count is $1,2,3,2,1,3,1,2,3, \ldots$.

Neither of the pieces contains further irregularities in the warp that are consistent throughout the full piece or appear in the middle section where both pieces once were joined. As the cutting line is curvy, weft-wise irregularities in this area should also match:

3. Double weft (fig. 9): The pattern has a horizontal mirror axis in the centre of the floral motif. The last cream weft of the upper pattern half of the panel is inserted double in the pattern shed and therefore shows as a thick cream weft. This is visible on the lower edge of the British Museum piece and, as a result of the curvy cutting, at the very top of the right side of the Victoria \& Albert piece.

As a result of the matching irregularities, it can be proven that both pieces were woven within the same warp as one decoration unit.

One irregularity gives further indications as to weaving details:

4. Broken and replaced binding warp thread (fig. 10): While the British Museum piece is intact in this area, in the Victoria \& Albert piece the usual brown binding warp $0.5 \mathrm{~cm}$ right of the left framing border and into the area with figures (thread No. 9 of left pattern field) ends in the central motif 4.7 $\mathrm{cm}$ after the horizontal mirror axis. After $11.5 \mathrm{~cm}$, with floating wefts, it is replaced by a blue warp thread, which runs all the way until the fringed lower end of the piece. It seems that the weaver repaired the broken thread with what he had at hand, even if the colour did not match perfectly. This repair leads to the conclusion that the weaving of the full panel started with the riders of the British Museum piece, and the Victoria \& Albert part of the sleeve panel was woven second. The fringes below the horsemen of the latter might indicate the end of the warp.

In addition to the conclusion that both pieces were woven as one decorative unit, the weaving direction can be identified.

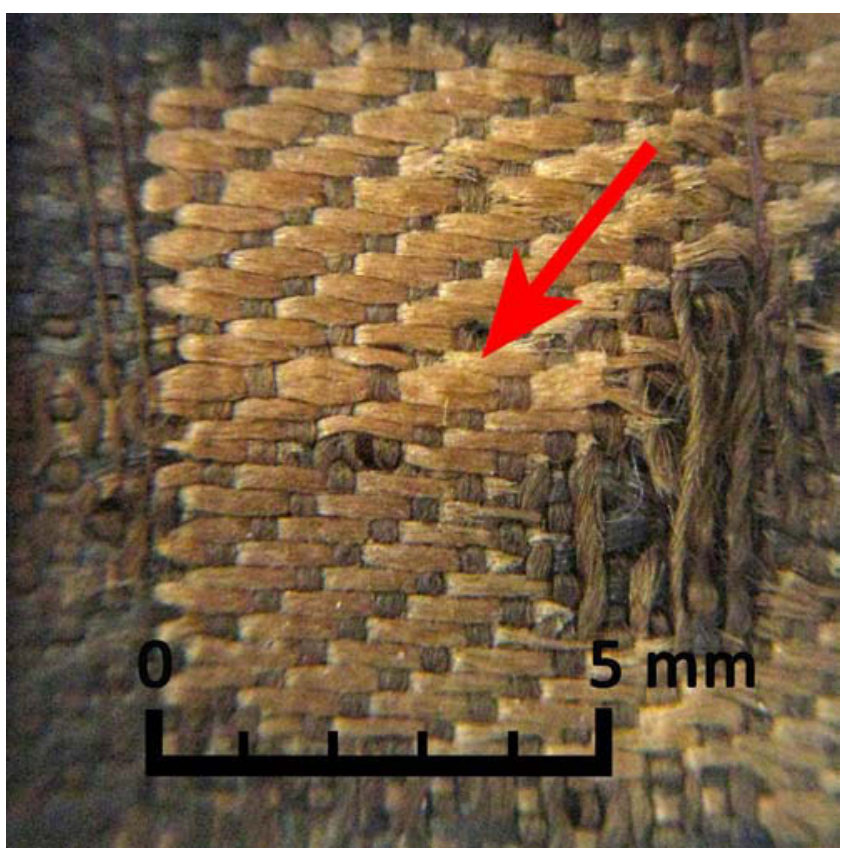

Figure 9a. Double cream weft in Victoria \& Albert Museum, Inv. No. 303-1887. (Photo: Barbara Köstner (C) taken courtesy of the Victoria \& Albert Museum).

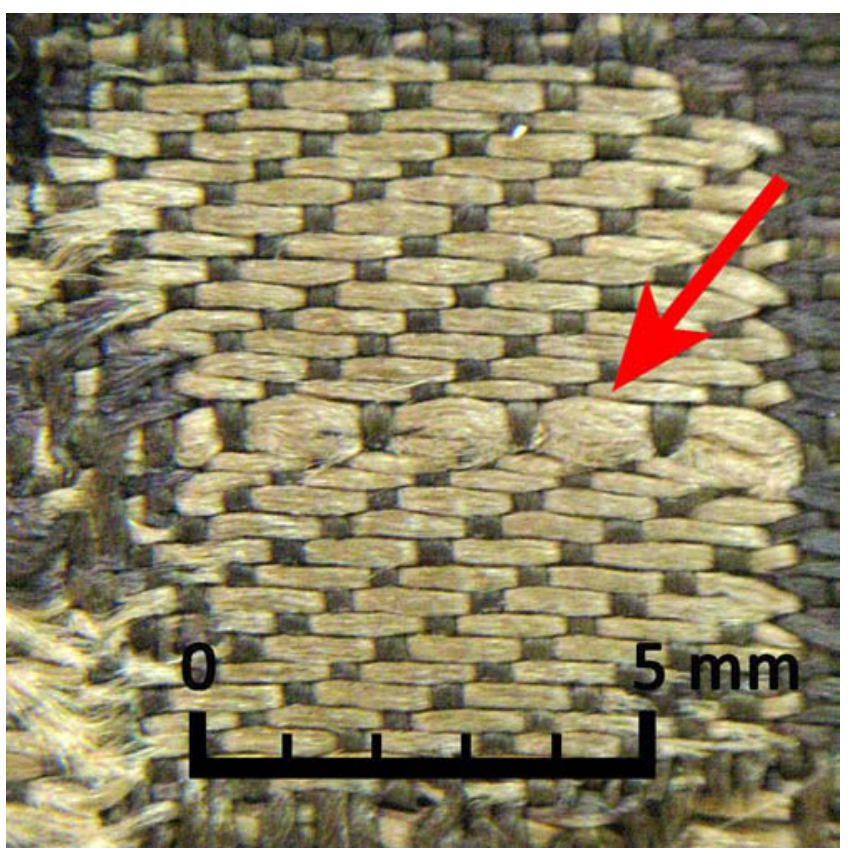

Figure 9b. Double cream weft in British Museum, Inv. No. 1904.0706, 41. (Photo: Barbara Köstner (c) taken courtesy of the Trustees of the British Museum). 


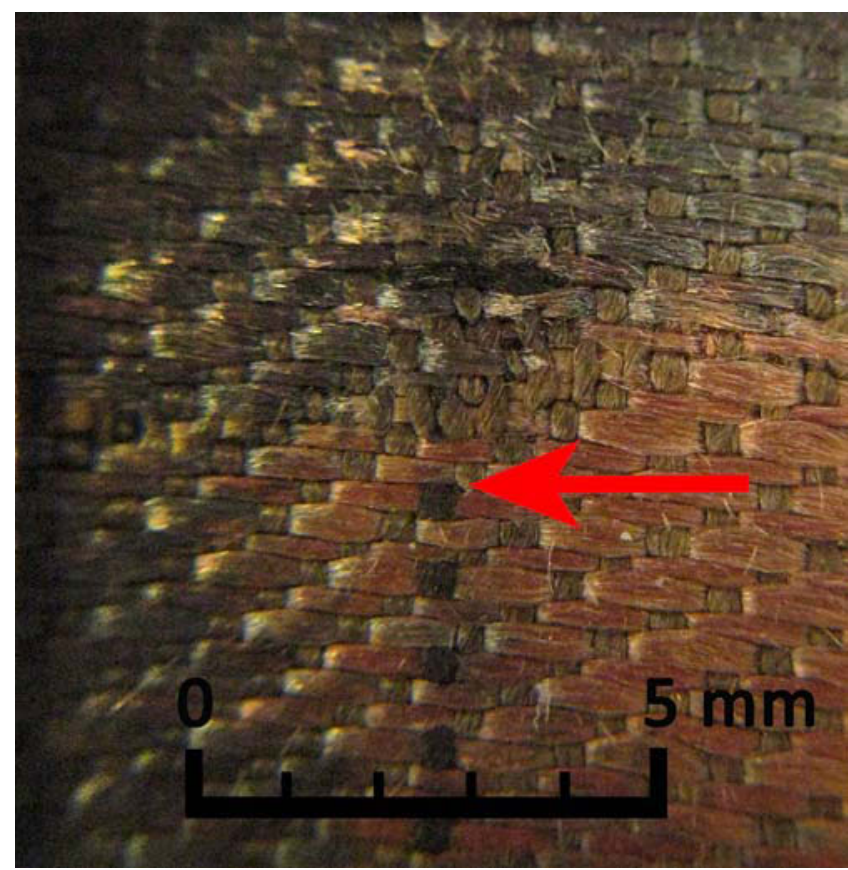

Figure 10. Broken and replaced binding warp thread in Victoria \& Albert Museum, Inv. No. 303-1887. (Photo: Barbara Köstner (c) taken courtesy of the Victoria \& Albert Museum).

But when were the pieces cut? As the sewing threads have been removed and the seam allowances of both pieces have been evened out, only very small remains and a few holes left by sewing threads have been detected on both pieces. ${ }^{6}$ The traces of sewing run along the left and right edges of the border and below the riders. In both pieces, 0.5-1 mm long stitches with 5-7 mm distance were found with sewing thread in a cream silk plied in S-direction from two thin silk strands. A horizontal line of wear close to the middle of the central field in the British Museum piece corresponds to traces of a sewing line placed immediately below and seen in the middle of the large sleeve panels on the Victoria \& Albert tunic, Inv. No. 820-1903. This line only appears on the British Museum piece; the upper edge of the
Victoria \& Albert half of the sleeve panel does not show any sewing traces. Further traces of wear indicate that the two objects have been exposed to pressure and wear as a unit. One line of wear runs through both pieces at the right side, moving towards the right border (see green line in fig. 6). These observations would lead to the suggestion that the pieces have been used and most probably applied to a tunic as a unit.

A look into the records of the fragments suggests that the pieces might have been cut in rather modern times: both panels were bought from the same collector, Henry Wallis, a painter, traveller, art collector and dealer from Biggin Hill, Norwood, London. He sold the first piece to the Victoria \& Albert Museum, then South Kensington Museum, in $1887 .{ }^{37}$ Seven years later, in 1904, the same Henry Wallis sold the second piece to the British Museum..$^{38}$ It is yet not possible to decide whether the pieces were already separated when Wallis bought them in Egypt. 39

\section{Conclusion}

This small example shows what the method is capable of. While the detailed technical data gives first hints as to the relationship of fragments with the same design, the unique pattern of irregularities proves they were woven in the same warp and belong to the same batch of fabric.

Tracing these batches helps to answer questions on the technically advanced looms used for silk samites. What was the width and length of the silk fabrics and how many pieces of tunic decoration could have been woven in one batch? How many batches were necessary to produce the variety of silk decorations? The relationship and differences between batches of the same design can also give clues regarding different weavers, looms and workshops. This could help to quantify the output of one workshop. At this stage we do not know what exactly the looms for weftfaced compound twills looked like and how they actually worked, ${ }^{40}$ but the technical analysis of irregularities helps to reconstruct them.

37. Archive of the Victoria \& Albert Museum, Museum Register No. 105, Science \& Art Department, MA/30/139, p. 167 and Nominal File MA/1/W330/2. The Nominal File did not reveal the origin of the textile, although the Registry states it was bought in Akhmim.

38. Remark in the entry of the British Museum's online collection, available at: https://www.britishmuseum.org/research/ collection online.aspx (last checked: 1/3/2019).

39. A visit to the British Museum's archive and the Bodleian Library, which holds Henry Wallis' papers and letters, may reveal further information.

40. No looms or written sources on the design of the looms are preserved for weft-faced compound twill from Late Roman to Early Medieval times. However, pattern looms from Han-Dynasty China are known through recently excavated and reconstructed models from Chengdou, $2^{\text {nd }}$ century BC (Zhao et al. 2017). Ethnological evidence for weaving weft-faced compound tabby is the zilu loom from Iran; see Thompson \& Granger-Taylor 1996. See also Sheng 2017. 
By finding out more about the technique and the looms for silk samite, the evolution of this weaving technology becomes tangible. One of the main goals of this archaeological research is to find information on the place of production of these western silk samites and the specialised looms and weavers connected to it. Combined with other methods, such as the analysis of dyestuffs, ${ }^{14} \mathrm{C}$ dating, iconographic analysis and research on the written documents as well as on the provenance of these fabrics, the outcome of this method helps to discover information on the possible origin of the silk samites.

\section{Bibliography:}

Baginski, A. \& Tidhar, A. (1978) "A Dated Silk Fragment from 'Avdat (Eboda)”, Israel Exploration Journal 28 (1/2), p. 113-115.

Burnham, D.K. (1980) Warp \& Weft. A Textile Terminology, Toronto.

CIETA (1964) Vocabulary of Technical Terms - C.I.E.T.A., Lyon.

De Moor, A., Schrenk, S. \& Verhecken-Lammens, Ch. (2006) "New Research on the So-called Akhmim Silks", in S. Schrenk (ed.), Textiles in situ. Their Find Spots in Egypt and Neighbouring Countries in the First Millenium CE. Riggisberger Berichte 13, p. 85-94.

De Moor, A., Verhecken-Lammens, C., Verhecken, A. \& Maertens, H. (2008) 3500 Years of Textile art: The Collection in HeadquARTers, Tielt.

von Falke, O. (1913) Kunstgeschichte der Seidenweberei: eine Auswahl der vorzüglichsten Kunstschätze der Malerei, Sculptur und Architektur der norddeutschen Metropole, dargestellt in einer Reihe der ausgezeichnetsten Stahlstiche mit erläuterndem Texte, Vol. 1, Berlin.

Forrer, R. (1891) Römische und Byzantinische SeidenTexilien aus der Gräberfelde von Achmim-Panopolis, Strasburg.

Forrer, R. (1895) Mein Besuch in El-Achmim. Reisebriefe aus Aegypten, Strasburg.

Galliker, J. (2013) “Application of Computer Vision to Analysis of Historic Silk Textiles”, in A. De Moor, C. Fluck \& P. Linscheid (eds.), Drawing the Threads Together. Textiles and Footwear of the $1^{\text {st }}$ Millennium AD from Egypt. Proceedings of the 7 th conference of the research group 'Textiles from the Nile Valley', Antwerp, 7-9 October 2011, Tielt, p. 150-163.

Gayet, A. (1897) “Catalogue des principaux objets recueillis au cours des fouilles et entrés dans les collections du musée”, Annales du musée Guimet, 26/3, p. 59-62.
Gayet, A. (1898) Ministère de l'instruction publique et des Beaux-Arts. Musée Guimet. Catalogue des objets recueillis à Antinoé pendant les fouilles de 1898 et exposés au Musée Guimet du 22 mai au 30 juin 1898, Paris.

Hampe, Th. (1896) Katalog der Gewebesammlung des Germanischen Nationalmuseums. 1. Teil: Gewebe und Wirkereien, Zeugdrucke, Nuremberg.

Herzog, A. \& Koch, P. (1958) Fehler in Textilien. Ihre Erkennung und Untersuchung, Krefeld.

Kendrick, A.F. (1922) Catalogue of Textiles from BuryingGrounds in Egypt. Vol. III: Coptic Period. London.

Martiniani-Reber, M. (1986) Lyon, musée historique des tissus. Soieries sassanides, coptes es byzantines $V^{e}-X I^{e}$ siècles. Inventaire des collections publiques françaises 30, Paris.

Muthesius, A. (1997) Byzantine Silk Weaving: A.D. 400 to A.D. 1200 , Vienna.

Noever, P. (2005) (dir.) Verletzliche Beute. Fragile Remnants. Beilage: Technische Analysen. Technical Analyses. Spätantike und frühislamische Textilien aus Ägypten. Egyptian Textiles of Late Antiquity and Early Islam, Vienna.

Paetz gen. Schieck, A. (2003) Aus Gräbern geborgen. Koptische Textilien aus eigener Sammlung. Krefeld 2003.

Sheng, A. (2017) "Chinese Silks that Circulated Among the Peoples North and West: Implications for Technological Exchange in Early Times?”, in B. Hildebrandt, \& C. Gillis (eds.), Silk. Trade and Exchange along the Silk Roads between Rome and China in Antiquity. Ancient Textiles Series 29, Oxford, p. 104-124.

Schulze, P. (1920) Alte Stoffe, Berlin.

Thomas, Th.K. (2007) "Coptic and Byzantine Textiles Found in Egypt: Corpora, Collections and Scholarly Perspectives", in R.S. Bagnall (dir.), Egypt in the Byzantine World, 300-700, Cambridge, p. 137-162.

Thomas, Th.K. (2017) "Perspectives on the Wide World of Luxury in Later Antiquity: Silk and other Exotic Textiles found in Syria and Egypt", in B. Hildebrandt \& C. Gillis (eds.), Silk. Trade and Exchange along the Silk Roads between Rome and China in Antiquity. Ancient Textiles Series 29, Oxford, p. 51-81.

Thompson, J. \& Granger-Taylor, H. (1996) “The Persian Zilu Loom of Meybod”, Bulletin of the Centre International d'Études des Textiles Anciens (CIETA) 73, p. 27-53.

Zhao, F., Wang, Y., Luo, Q., Long, B., Zhang, B., Xia, Y., Xiao, L. (2017) “The Earliest Evidence of Pattern Looms: Han Dynasty Tomb Models from Chengdu, China”, Antiquity 91 (356), p. 360-374. 